\title{
Open Universities: Innovative Past, Challenging Present, and Prospective Future
}

\author{
Sarah Guri-Rosenblit \\ The Open University of Israel
}

\begin{abstract}
This article examines the innovative past of the large-scale, single-mode open universities that follow the model of the UK Open University (UKOU), analyzes the main challenges which they are currently facing in the digital era, and concludes with highlighting leading prospects for their future operation.

The establishment of the UKOU in 1969 marked a new era in distance higher education. It gave distance education a new legitimacy and opened up new prospects for populations that for a variety of reasons were unable to attend a campus-based university. Many of the new open universities were heralded as a conspicuous development in higher education, with innovative features such as: open access, reaching out to part-time adult students, providing academic faculty the opportunity to work in teams to prepare study materials, modular credit accumulation, teaching huge numbers of students, and harnessing innovative technologies into their teaching/ learning processes.
\end{abstract}

In the last three decades, many of these innovative characteristics pioneered by open universities have been adopted by campus universities. This has eroded the unique status of open universities in many national jurisdictions. Furthermore, the emergence of digital technologies has challenged the underlying premises of the industrial model of many open universities, as well as their logistic operation. Present challenges facing open universities emerge from: blurred boundaries between distance and campus universities; the changing of initial target populations; the need to restructure the technological and logistic infrastructure of open universities; the changing roles of the academic faculty; and the growing competition for both students and funds. In order to find success and keep being relevant in the future, open universities should take into consideration: future target populations; the use of MOOCs and OER; support systems for both students and professors; collaboration with other higher education institutions; collaboration with the corporate and work worlds; and enhancing the academic status of open universities.

Keywords: distance education, open universities, distance teaching universities, e-learning, digital technologies 


\section{Introduction}

The establishment of the UK Open University (UKOU) in 1969 was considered to be a breakthrough in higher education. Its impact on the development of single-mode distance teaching universities worldwide has been extraordinary. While struggling for respect at home, the UKOU has served as a model of imitation and guidance abroad. It has improved the image of distance education at the higher education level enormously. Many have heralded new open universities as the most conspicuous development in higher education in recent decades and as a new academic tradition (Shaw \& Taylor, 1984), as a radical challenge to the concept of a university (Keegan \& Rumble, 1982), as the new temples of learning (Reddy, 1988), and as a new species of university (Perry, 1977).

The terms open universities or distance teaching universities are, of course, generic terms and as such cover many variations and differences in purpose, practice, and paths of development in different countries. There are currently around 60 single-mode distance teaching universities around the world (Tait, 2018). Most of these single-mode distance teaching universities have not adopted an open admission policy, even though they are entitled as an open university, but instead portray openness in many other dimensions (Guri-Rosenblit, 1999, 2014). In this article, the terms open universities and distance teaching universities (DTUs) are used interchangeably.

Disbanding the campus and reaching out to students to allow them to study wherever and whenever they prefer is the feature which has distinguished open/ distance teaching universities from mainline, residential campuses for nearly 150 years. UK and Canada have a long history of correspondence education dating back to the $19^{\text {th }}$ century. Thus, the UKOU was not innovative in offering distance higher education. In 1858, London University opened its gates to all commonwealth candidates in several academic programs. But the UKOU has been innovative in many other ways, such as by: adopting an open access policy, reaching out to part-time adult students, enhancing teamwork of academic faculty in preparing high quality study materials, introducing the modular credit accumulation in the English higher education system, teaching huge numbers of students, and harnessing innovative technologies into its teaching/ learning processes. In many other countries, like Spain, Germany, Israel, China, and Japan, the concept and practice of distance teaching at a university level was novel and revolutionary until the early 1970s, and offering higher education through distance teaching methods has constituted the main innovative characteristic of some of the new DTUs (Guri-Rosenblit, 1999).

During the last three decades, many of these innovative characteristics pioneered by open universities have been adopted by campus universities. The unique status of open universities as leading breakthrough innovations in many national jurisdictions has been eroded. Furthermore, the emergence of digital technologies has challenged the underlying premises of the industrial model and the logistic operation of large-scale open universities. Drastic governmental budget cuts in many countries have put the operation of several DTUs in a most vulnerable position. Open universities are currently challenged by: blurring boundaries between distance and campus universities; change of their initial target populations; need to restructure their technological and logistic infrastructure; changing roles of their academic faculty in the digital era; and growing competition between them and campus-based universities for both students and funds.

The article concludes by highlighting the leading future prospects for open universities in relation to: future target populations; the use of MOOCs and OER; support systems for both students and 
professors; collaboration with other higher education institutions; collaboration with the corporate and work worlds; and enhancing the academic status of open universities.

\section{Innovative Past}

Open universities, and the UKOU in particular, have introduced many innovative features into the academic higher education systems within which they operate. Clearly, academic cultures vary greatly. In some countries, the very introduction of providing higher education through distance education methods has constituted an enormous innovation, like in Germany, Spain, Israel, China, and Japan, whereas in other countries many breakthrough innovations were pioneered by the single-mode DTUs.

The UKOU was the most daring and innovative university in the context of the UK higher education system. As aforementioned, it was not innovative in offering distance education at the university level. However, the UKOU challenged long-standing assumptions in the UK higher education system and revised many common traditions by: demanding no entry qualifications in a strongly elitist higher education system; opening the university gates to part-time adults who were commonly ignored by other universities; challenging the ethos of academic freedom by inventing the course team approach for developing courses; its establishment from the outset as a mega university contrary to the British tradition of small universities; being the first university in the English higher education to adopt a modular system; and by basing its operation on a partnership with the BBC in order to mobilize mass media for the benefit of higher education. Many open universities worldwide followed its suit, adopting some of UKOU's innovative features.

\section{Open Access to Higher Education}

Broadening access to higher education is a concern of all open universities. Without any doubt, the opening of access to a university degree, without the setting of any entry requirements by some open universities such as the UKOU, Athabasca University in Canada, and The Open University of Israel, conflicted drastically with the traditional meritocratic concept of selective admission to university studies. In the context of the elite higher education systems of the UK and Israel, this was particularly revolutionary.

DTUs including Universidad Nacional de Educación a Distancia that was founded in 1972 as the only national university in Spain, and the FernUniveristät that was established in 1973 in the land of North Rhine Westphalia in Germany - have not adopted an open admission policy. This rejection of the open admission policy arose from the concern that such a policy would alienate these DTUs from the mainstream universities and put them in an inferior position. However, these DTUs were innovative in terms of offering higher education through distance teaching methods, as well as by providing flexibility in time, place, and pace of study (Guri-Rosenblit, 1999; Keegan \& Rumble, 1982; Peters, 1994).

\section{Part-Time Adult Students}

Nowadays, part-time adult students constitute an important segment of the student body in higher education worldwide. Part-time provision is perceived as a pragmatic means for expanding access to higher education, by enabling students to combine study with work, domestic and social 
responsibilities, health restrictions, army service, etc.; however, this was not the case in many countries in the early 1970s.

The UKOU has been clearly committed to part-time adult students from its initial establishment. Walter Perry, the first Vice-Chancellor of the UKOU argued that providing higher education to parttimers was the most important goal of the UKOU. The overriding view in the UK academic community in the 1960s was that part-time higher education was not part of their responsibility. It was this view that perpetuated the gap in higher education provision for part-time students in the UK (Perry, 1977).

In many other countries, such as Spain, Germany, and Israel, at the time when open universities were established-part-time higher education was a common practice at campus universities as well. Catering for part-time, employed adults, was not a break from tradition in these countries (GuriRosenblit, 1999).

\section{Teamwork}

Some open universities presented a threat to the prevalent ethos of academic freedom by defining stringent quality assurance procedures to ensure the high quality of the instructional materials, and by implementing a teamwork approach in teaching. The UKOU pioneered the model of teamwork in preparing high quality self-study courses. For the design of each course, a team made up of academics, educational technologists, television and radio professionals, editors, tutors, and others as needed, was formed. Within this team, the writing of the academics was evaluated both by other academics in the team or by academics from other universities. Scaled-down versions of UKOU's teamwork model were later adopted by many open universities. Perry (1977) stated that during the recruitment process of the academic staff to the UKOU, it was made abundantly clear that the conventional academic freedom in teaching could not and would not be available to the academic staff of the UKOU. Perry reckoned that academics took this limitation on their academic freedom in different ways. Some found it relatively straightforward, while others had difficulties in coming to terms with this policy, and thus refrained from joining the academic faculty at the UKOU (Perry, 1977). In contrast, during the development of DTUs in Germany and Spain, quality assurance procedures and teamwork were not obligatory, and thus were not forced on the academic staff of DTUs (Guri-Rosenblit, 1999). Academics at the Spanish and German DTUs were even permitted to refuse the employment of an editor to edit and revise their writings (Guri-Rosenblit, 1999; Peters, 1983, 1994).

Today, teamwork is a common practice in preparing Massive Open Online Courses (MOOCs), Open Educational Resources (OER) and online courses worldwide by academics from both campus-based and distance teaching universities (Bonk, Lee, Reeves, \& Reynolds, 2015; De Corte, Engwall, \& Teichler, 2016; Lane, 2017; Pappano, 2012). Unquestionably, the UKOU introduced the use of teamwork as means to prepare high-quality teaching materials to the academic world.

\section{Reaching Out to Large Numbers of Students}

Open universities, by their very nature, were established to become large-scale universities. Daniel (1996) defined DTUs that teach over 100,000 students as mega-universities. He argued that some of the key strengths and weaknesses of mega-universities are due to their absolute size. The financial base associated with their size allows them to make substantial financial investments in new technologies and enables them to invest large amounts of money in developing high quality study 
materials. However, to teach huge numbers of heterogeneous student populations entails both logistic and didactic difficulties.

Today, some DTUs have reached an enormous size. Indira Gandhi University is considered to be the largest university in the world with over 4 million students. In 2015, The Open University of China enrolled over 2.7 million students, and in 2017, Anadolu University in Turkey enrolled around 2.9 million students. Clearly, the scale and the logistics of mega-universities creates an inertia not found in smaller institutions, and distinguishes them from small higher education institutions.

\section{The Modular System}

The modular system in higher education is prevalent today in all higher education systems. Most universities divide their degrees into courses and operate some variant of the credit accumulation system. Considerable differences exist between credit sizes across various higher education systems. The requirement for an undergraduate degree might range from six large courses to over 30 courses. The modular credit system originated at Edinburgh University in Scotland in the early $18^{\text {th }}$ century and reached full flower in the United States (Rothblatt, 1991). Thomas J efferson had a Scottish tutor, and J efferson introduced the credit system when founding the University of Virginia in the mid 1820s (Rothblatt, 1991). The modular system was eventually adopted by all higher education systems worldwide.

Interestingly, though the modular idea was initiated in Scotland, it was not quickly adopted by the English higher education system. The UKOU was the first English university to adopt a modular system. The Scottish influence on the UKOU was undeniable. Both J ennie Lee, the leading champion of the university, and Walter Perry, its first Vice-Chancellor, were Scottish. When developing the credit system for the UKOU, Lee and Perry agreed that the Scottish system was most useful for adaptation. For an ordinary Bachelor or Arts (BA) degree at Scottish universities, students were required to take a minimum of seven courses. At the UKOU, it was decided that six courses would be required for an ordinary BA and eight courses for an honors degree (Perry, 1977). The UKOU was a harbinger which had envisaged the need to change the traditional concept of a unified and coherent curriculum structured and monitored closely by a tutor. Today, most UK universities employ a modular system aligned with the Bologna European Credit Transfer System.

\section{Harnessing Advanced Technologies}

Open universities owe a great part of their subsequent fortunes to their early and rapid marriage with communication technology (Daniel, 1996; Guri-Rosenblit, 1999) The open universities that were established in the 1970s and 1980s were regarded by many as the universities of the air (GuriRosenblit, 2010). Television in those days was the queen of the media, and the new open universities were expected to harness the technology of mass communication for the purposes of higher education (Guri-Rosenblit, 1999; Conole, 2014).

The initial idea of creating a new, single-mode distance teaching university in the UK reposed on the idea of mobilizing mass communication media for the transmission of lectures through the UK. From this, the UKOU created a partnership with BBC, though its main teaching mode relied on printed selfstudy materials. Several DTUs were based entirely on teaching through mass media. Since its establishment in 1979, China Central Radio and TV University (now called the Open University of China) has used TV and Radio to transmit lectures to students. The University of the Air in Japan 
(renamed in 2007 as the Open University of Japan) was established in 1985, and its instructional media included TV, radio, and satellite transmissions. The Korean Open University was established in 1972 as a branch of the Seoul National University, and in 1982 became the Korean National University. It transmitted lectures through a domestic cable TV until the emergence of the digital technologies (Guri-Rosenblit, 2010). However, mass communication media are not the leading technologies nowadays (Bates, 2015; Bates \& Sangra, 2011; Branch, Bartholomew, \& Nygaard, 2015; Contact North, 2018; Guri-Rosenblit, 2010, 2018). Unquestionably, the new digital technologies have a deeper and stronger impact on all higher education institutions as compared to mass media technologies. The idea of harnessing advanced technologies for the benefit of higher education is widely accepted today.

\section{Challenging Present}

The success of open universities has prompted campus-based universities in the last decades to adopt many of their innovative practices. It seems that once innovative efforts gain success, they become quite attractive to those who earlier judged such ventures to be mere folly. Open universities have thus evolved from being viewed as a daring experiment in higher education to a strategic provision of higher education. The emergence of the digital technologies has prompted many of the campus universities to reach out to students beyond their campuses by offering fully distance or blended programs. New technologies also gave birth to many new distance education providers. Some are public institutions, whereas many are for-profit private entities.

Today, DTUs are facing many challenges. In the relevant literature, a growing number of policy papers and publications have been concerned with the sustainability of the open university model (Commonwealth of Learning, 2017; Garrett, 2016; Guri-Rosenblit; 2014; Tait, 2018). The following section outlines the major challenges currently faced by open universities.

\section{Blurred Boundaries Between Distance and Campus Universities}

For nearly 150 years, the distinction between mainstream campus and distance education was clear. By its very nature distance teaching at higher education level was different from teaching at mainstream universities. Instead of assembling students from dispersed destinations onto one campus, distance teaching institutions have reached out to students wherever they live or wish to study. However, the function of providing education to students wherever they live or wish to study is no longer unique to distance teaching universities. Today, new digital technologies enable campus universities to reach out to students outside of their residential campus and to offer online courses to both off-campus and on-campus students. These blurred boundaries between distance and campusbased institutions have led to an identity crisis for some of the single-mode DTUs, challenging their raison d'être and eroding their unique status in their national jurisdictions (Commonwealth of Learning, 2017; Guri-Rosenblit, 2014; Tait, 2018).

\section{Change of Initial Target Populations}

Participation rates in higher education in many countries were quite low when open universities were established in the 1970s and the 1980s - between 8\% to 30\% (Guri-Rosenblit, 1999). In addition, provision of higher education to part-time students was very limited in some countries. Thus, there was a high demand in all DTUs for part-time study at the undergraduate level. Furthermore, some 
professions have started to upgrade their position to an academic status since the 1970s. For example, in the 1970s and 1980s, teachers constituted a large student cohort in the UKOU, the Open University of Israel, and Terbuka University in Indonesia (Guri-Rosenblit, 1999; Tait, 2018).

Today, participation rates in higher education are very high in most European countries and in North America. Participation rates in higher education fluctuate between $50 \%$ to $85 \%$ of relevant age cohorts (Tait, 2018). As a result, there has been noticeable decline in enrollment at the undergraduate level in many DTUs in the last decades. Governmental budget cuts have also affected the demand for parttime study at the bachelor level in some open universities. UKOU, for instance, lost as much as third of its students in the last decade as a result of new regulations concerning government funding of part-time students (Garrett, 2016; Tait, 2018).

Open universities in Europe, North America, as well as in some parts of Asia, have thus had to define alternative target populations to ensure their sustainability in their national jurisdictions. Potential students for open universities might be: those looking for professional upgrade, short cycle diplomas, or postgraduate degrees; younger students (even at the high school level); or transnational students.

\section{Need to Restructure the Technological and Logistic Infrastructure}

The digital technologies have challenged the economic and logistic infrastructure of large-scale DTUs, based on the industrial model of the UKOU (Guri-Rosenblit, 1999; Peters, 1983, 1994; Rumble, 2014). The search for less expensive ways of providing higher education to large numbers of students was one of the main considerations behind the establishment of the large DTUs by national governments in the 1970s and 1980s. The industrial model of distance education succeeded in creating an admirable equilibrium between being able to absorb unlimited numbers of students while still monitoring tightly the quality of the study materials and the study process at a lower cost as compared to conventional campus universities.

One positive impact of the new technologies in the context of DTUs, is that they enable teachers to update study materials on an ongoing basis, as well as facilitate interaction between students and teachers, and among students. In other words, the new technologies alleviate two of the major disadvantages of traditional distance teaching. However, at the same time, these new technologies also highlight the importance of interactions with expert teachers in the actual study process (Bates \& Sangra, 2011; Conole, 2014; Guri-Rosenblit, 2010; Harasim, 2012). Most large-scale DTUs are based on relatively small academic staffs, and cannot afford the hiring of additional academics in order to facilitate student-professor interaction in most of their large courses, studied frequently by thousands of students. The reality is that most large scale DTUs lack the appropriate infrastructure and human capital to use the new technologies broadly and efficiently (Guri-Rosenblit, 2010, 2014; Rumble, 2014). To use the new technologies for online learning and teaching demands a major overhaul of the whole operation of the veteran DTUs, and a huge investment in setting up a totally new infrastructure for developing and delivering courses.

\section{Changing Roles of Academic Faculty}

The roles of academic faculty, both in open universities and in campus-based universities, have been changing dramatically in the last two decades (Guri-Rosenblit, 2018). The incorporation of new technologies in DTUs force academic staff to assume new responsibilities and to develop a whole range of new skills. The industrial teaching model pioneered by the UKOU is based on the notion of 
distributing teaching responsibilities between the senior academic staff, course coordinators, and tutors. In some open universities, like the Open University of Israel, the senior academic staff are mainly responsible for developing study materials and are not involved directly in the teaching process. However, the use of the distributed teaching responsibility model is less possible in the digital age, in which students expect to interact directly with their teachers.

Universidad Oberta de Catalunya (UOC), which was established in 1995 as an online university, has relied from its very outset on a totally different teaching model for distance delivery. It currently employs around 300 senior academic faculty and more than 2,000 professors from campus-based universities in Spain and Latin America as adjunct professors on a part-time basis. The University of Maryland University College also employs full-time academic faculty and adjunct faculty for online teaching, and has never adopted the distributed teaching responsibility model.

Academic faculty in many DTUs feel reluctant to support the move towards the development of digital courses and to engage actively in online teaching because it entails a dramatic change in their roles and obligations (Guri-Rosenblit, 2018). Academic faculty need to learn how to use data provided by Learning Analytics, monitor closely the study process of students, and to be able to use MOOCs, open educational resources, and other digital resources in developing courses and in the teaching process. They also need to learn how to engage in e-chats and other online activities. Definitely, the use of the new technologies entails acutely different requirements of the teachers as compared to their current roles as academics in the industrial model of distance teaching delivery.

\section{Growing Competition}

Most large distance teaching universities were established as a product of governmental planning assigned to fulfill national missions (Guri-Rosenblit, 1999). They were born in a period when governments funneled large amounts of public funds into higher education for the building of new institutions and the expanding of existing ones. This situation has changed dramatically in the last decades. The enormous expansion of higher education led many governments to drastic budget cuts in supporting higher education institutions. Universities are encouraged today to become entrepreneurial in nature and mobilize funds by raising tuition fees, as well as by relying on the corporate world, philanthropic donors, and business-like ventures.

In addition, open universities today face fierce competition for potential students from campus-based universities that offer fully online programs, as well as from new distance education providers. Very few governments protect the unique status of open universities as sole providers of distance education (Garrett, 2016; Tait, 2018). In China, for instance, the Radio and TV Universities Network that was established in 1979 was the sole distance education provider in China for twenty years. From 1999 onwards, 68 online colleges in campus-based universities were authorized by the Chinese Ministry of Education to offer online/ distance degrees and professional diplomas, focusing mainly on continuing education and professional upgrade ( $\mathrm{Li}, 2012$ ). Since 2014, the Chinese Central Government abolished the regulation that new online/ distance education programs need to be authorized by the government and enabled any Chinese university to offer online/ distance degrees and diplomas (J . Xiao, personal communication, November 10, 2015).

Major strategies that open universities can adopt to respond to the growing competition for students and funds include: to reach out to new target populations, to collaborate with other competing 
institutions in an attempt to reduce the competitive risk, to increase collaboration with the work and corporate worlds by designing tailor made programs, and to strengthen their relative advantages and demonstrate excellence in specific areas.

\section{Future Prospects}

Despite the immense challenges that open universities are currently facing, they still hold a huge potential for playing an important role in both national and international contexts. It is of tremendous importance that their leaders invest efforts to redefine their future target populations, consider how to use MOOCs and OER efficiently in order to reduce costs and secure high quality materials, provide efficient support systems for both students and professors, collaborate with other higher education institutions and with the corporate and work worlds, and enhance the academic status of open universities by scoring high on excellence in teaching and promoting high level research in designated areas.

\section{Future Target Populations}

It is important to distinguish between potential student clienteles of DTUs in different parts of the world. Significant growth in number of students will take place in the next decades, primarily in the countries of Asia, Africa, and Latin America (Tait, 2018). Open universities in Europe and North America will have to look for potential new target populations.

As aforementioned, many DTUs have suffered in the last decade from an enrollment decline at the undergraduate level due to fierce competition from traditional campus universities and new providers of online education. Governmental budget cuts to DTUs have further contributed to the decline of part-time demand in some countries. Leaders of open universities should define new potential target groups. One such group may be students from highly disadvantaged backgrounds that cannot be admitted at other universities or higher education institutions. Garrett (2016) believes that the core target group for open universities in the future is composed of students that come from very low social and educational backgrounds. He argues that DTUs should provide adequate support mechanisms for such students (Garrett, 2016).

It is also advisable for open universities to reach out to students from strong backgrounds - such as students who already possess a bachelor's degree or even a postgraduate degree, who are looking for short cycle programs mainly for professional upgrade. Bates and Sangra (2011) claim that lifelong learning has become critical for the economic development of knowledge-based economies. From this, Bates and Sangra (2011) predict that the market for lifelong learning for professional update will grow immensely in the future, and that this market will be at least as great as the market for students leaving high school for university and college studies. Students opting for diploma studies and continuing professional education will enroll either as individuals or more likely as members of organized groups, on the basis of contracts signed between the universities with firms and enterprises in the corporate world. DTUs are well equipped for providing a rich spectrum of opportunities for professional upgrade.

Another potential student population for some open universities might be young, high school students who are excelling in their studies. At the Open University of Israel (OUI) there is a growing number of 
high school students, excelling mainly in mathematics, sciences, and computer science, that study towards an academic degree at the open university concurrently with studying at high school. Some even succeed in completing a bachelor's degree concurrently with their matriculation exams. Such young high-level students need a special nurturing environment. Another growing group of students at the OUI are soldiers in the process of completing their three-year compulsory service. Offering service members an array of disciplines to choose from, OUI enables service members to complete their first year of a bachelor's degree. The completion of all requirements of a first academic year at the OUI allows soldiers to then enroll at other universities for their second year of academic study. Agreements between the OUI and other Israeli universities set a priori conditions for transferring to a second year of study after completing first year courses and passing first year exams with high grades.

Transnational students constitute an additional potential target population for open universities. The International Telematic University (UNINETTUNO) in Italy that was established in 2005 develops courses in four languages: Italian, Arabic, English, and French, aimed mainly for students in the Mediterranean region (The International Telematic University, 2018). Open universities that teach in English or Spanish are in a favorable position to reach out to transnational students (Guri-Rosenblit, 2010, 2014).

\section{Use of MOOCs and OER}

Massive Open Online Courses (MOOCs) and the open source movement producing Open Education Resources (OER) hold a special promise for open universities. MOOCs are a recent development in distance education. They were first introduced in 2008 and emerged as a popular mode of learning in 2012 (De Corte et al., 2016; Lane, 2017; Pappano, 2012). A MOOC is an online course aimed at unlimited participation and open access via the Web. In addition to traditional course materials such as filmed lectures, readings, and problem sets, many MOOCs provide interactive user forums to support community interactions among students, professors, and teaching assistants.

MOOCs were initiated by elite American universities, and now many universities around the world are following suit. In Europe, the MOOCs movement is being led by the UKOU and by the European Association of Distance Teaching Universities (EADTU). In 2012, the UKOU initiated the FutureLearn project - collaborating with 143 partners (including non-university partners) in preparing MOOCs and nano-programs aimed mainly for postgraduate students and for professional upgrade (FutureLearn, 2018). In 2014, EADTU initiated the HOME project, which stands for: Higher Education Online: MOOCs the European Way. The aim of HOME is to develop and strengthen an open network for European cooperation on open education in general, and MOOCs in particular (EADTU, 2018). However, currently, a minority of open universities produce MOOCs or use them as an integral part of their teaching. MOOCs and OER have the potential to reduce costs of developing study materials, as well as to enable the academic faculty at open universities to devote more time to engage in actual teaching and assist in assuring high quality study materials.

\section{Support Systems}

Successful online learning demands much more of students and teachers than understanding how to navigate a learning management system, download files, and design PowerPoint presentations. Though most students are accustomed today to using technology in their personal and social lives, they do not necessarily know how to use technology efficiently in their studies. 
Students need digitally confident teachers. However, most academic faculty are not well equipped to guide students in developing digital competencies. Many studies in the relevant literature dealing with the implementation of digital technologies in academia specify a long list of roles which teachers are expected to undertake in online teaching, such as: monitoring students' learning by providing ongoing feedback; identifying and resolving instructional, interpersonal, and technical problems; and being responsible for creating a learning community. Such roles are often very different from teachers' typical teaching responsibilities. For DTU teachers, this change of roles entails work overload with no appropriate compensation, which partially explains the resistance of academic faculty at many universities, including open universities, to transfer to online teaching (Guri-Rosenblit, 2018).

Most universities today, including DTUs, are not employing widespread strategies to address the digital literacy needs of their academic faculty and students. To enable professors to make the most of new technologies and the various teaching tools these technologies offer, necessitates a conceptual redefinition of the academic faculty's roles, and well-designed training and ongoing support systems for both students and teachers. As technologies continue developing and new uses proliferate, the meaning of digital literacy will continue to evolve. Thus, the support systems for both students and teachers should operate on an ongoing basis, and continually adjust to new technological tools and practices.

\section{Collaboration With Other Higher Education Institutions}

Leaders of DTUs should identify and define clearly both their potential competitors and collaborating parties in academia within national boundaries and beyond them. Partnerships, if they are successful, create greater strengths. The basic underlying idea behind cooperation is that the whole may be greater than the sum of its parts. Failure to collaborate often results in an unnecessary duplication of efforts and in ineffective investments of scarce resources.

Successful inter-institutional collaborations of DTUs have the potential to attract new student clienteles, reduce costs for course development, enhance flexibility, ensure high quality mechanisms, provide richer and better programs, and strengthen the financial basis of distance teaching institutions. Finding appropriate partners and maintaining a fruitful collaboration constitute two of the most challenging tasks that are crucial for the future operation of DTUs.

The FutureLearn initiative of the UKOU described earlier, constitutes such an effort of joining forces between many universities, both campus-based and distance teaching universities (in addition to nonuniversity partners), to produce high quality programs that are aimed to serve a huge variety of students. In 2015, The Open University of Israel (OUI) established an Online Academia subsidiary company whose main target is to produce high level online courses in collaboration with academic faculty from the 61 other universities and colleges in Israel. It also created many collaborative agreements with universities to ensure a flexible transfer of its students who study introductory courses at the OUI to fields of study that do not exist at the OUI. Such transfer channels mainly serve high school students and soldiers in compulsory service.

\section{Collaboration With the Corporate and Work Worlds}

DTUs are by their very nature inclined to create a closer interface with labor markets and the corporate world. From their outset, many DTUs have appealed to professional groups, such as teachers, nurses, engineers, technicians, and public employees, and have designed a variety of 
programs geared towards professional upgrade. Throughout the years, many DTUs have redefined their initial priorities in order to meet changes in labor markets and societal demands. Today, many open universities offer continuing education programs tailored to the special needs of particular professions, and to the unique requirements of special firms.

In today's workforce, employers are increasingly interested in what potential employees can do rather than what or where they studied. Many professional bodies are moving toward competency-based and mastery models for admission to the profession. These include project management, nurse and medical education, some engineering professions, and many more (Contact North, 2018). Over the coming decades we can expect more professional bodies and workplaces to adopt a competencymastery approach to professional certification. Nano-degrees and mini-masters, which might easily be offered by open universities, may greatly accommodate this trend. Open universities are thus in a strong place to offer appropriate programs for the benefit of professional upgrade (Contact North, 2018; Ubachs, Konings, \& Brown, 2017).

\section{Enhancing the Academic Status of Open Universities}

It is of tremendous importance for open universities to enhance their academic status both within national boundaries and across international networks. Excelling in teaching has been a clear mission for open universities from their initial establishment. It is of outmost importance that they continue to be leaders in implementing innovations into higher education teaching. Many open universities have been ranked highly in student's national surveys in different countries. The OUI, for instance, was ranked from 2014 to 2019 as the top university in the national student's association satisfaction survey, in the parameters related to excellence in teaching and efficient incorporation of the digital technologies into the learning/teaching processes (Open University of Israel, 2019). DTUs should continue putting an emphasis on enhancing their excellence in teaching.

Academic status is manifested today in an array of league tables. International university rankings have become a familiar character of the higher education scene in the last two decades (Federkeil, 2011; Millot, 2014). International league tables started in 2003, and were geared at the beginning for identifying leading research universities. An additional underlying premise behind the ranking tables relates to the growing importance of providing reliable information to the clients and consumers of higher education. The ranking tables assist in providing relevant information to student clienteles comparing various potential higher education institutions before deciding where to enrol. There are today over 50 ranking tables that position higher education institutions worldwide according to various indicators (Federkeil, 2011).

The two most important league tables for highlighting leading research universities are the J iao Tong Shanghai World University Ranking (Shanghai Ranking, 2018) and the Times Higher Education Supplement Ranking (Center of World University Ranking, 2018). Open universities, by their very nature, have not been designed to be leading research universities. But they might lead high quality research in a few relevant areas of their operation, such as: the impact of digital technologies in higher education, cognitive science focusing on adult learning, learning analytics, etcetera. UKOU, for instance, was positioned in the group of 301-400 leading research universities in the Shanghai Rankings from 2003-2010. From 2011 to 2014, UKOU dropped to the 401-500 group. From 2015 onwards it disappeared from the Shanghai Ranking (Shanghai Ranking, 2018). However, the UKOU still ranks high in its national boundaries. It was ranked 36 th among 132 universities in the UK by the 
Times of Higher Education Ranking in 2018 and 498 th in the world in a list of 1,000 leading universities in the world (Center of World University Ranking, 2018).

The OUI allocated in the last decade a generous budget to promote research centers in three main areas - digital technologies, social media, and the three Abrahamic religions. It is likely that investing in promoting high level research in a few designated areas relevant to their operation, will greatly assist DTUs in enhancing their academic status both in national and international settings. 


\section{References}

Bates, A. W. (2015). Teaching in a digital age: Guidelines for designing teaching and learning for a digital age. Victoria, BC: Open Textbook Project.

Bates, A. W., \& Sangra, A. (2011). Managing technology in higher education: Strategies for transforming teaching and learning. San Francisco: J ossey-Bass.

Bonk, C. J ., Lee, M. M., Reeves, T. C., \& Reynolds, T. H. (2015). MOOCs and open education around the world. Abington, UK: Taylor \&Francis.

Branch, J., Bartholomew, P., \& Nygaard, C. (2015). Technology enhanced learning in higher education. Faringdon, UK: Libri.

Center of World University Rankings. (2018). World university ranking 2018-2019. Retrieved from https:// www.timeshighereducation.com/world-university-renkings/open-university

Commonwealth of Learning. (2017). Open universities in the commonwealth: At a glance. Burnaby, BC: Commonwealth of Learning. Retrieved from http:// oasis.colorg/ handle/11599/2786

Conole, G. (2014). The use of technology in distance education. In T. Anderson \& O. Zawacki-Richter (Eds.), Online distance education: Towards a research agenda (pp. 217-235). Edmonton, AB: Athabasca University Press.

Contact North. (2018). Teaching and learning in the digital age: A new understanding of quality. Retrieved from https:// teachonline.ca/ tools-trends/insights-online-learning/ 2018-0207/ teaching-learning-digital-age-new-understanding-quality

Daniel, J . S. (1996). The mega-universities and the knowledge media. London, England: Kogan Page.

De Corte, E., Engwall, L., \& Teichler, U. (2016). From books to MOOCs? Emerging models of learning and teaching in higher education. London: Portland Press with Wenner Gren.

European Association of Distance Teaching Universities. (2018). About HOME. Retrieved from https:// home.eadtu.eu/38-abouthome

Federkeil, G. (2011). Academic rankings: New developments. Paper presented st the First International Seminar on Higher Education Rankings and E-Learning, Barcelona.

FutureLearn. (2018). Meet our university partners. Retrieved from https:// www.futurelearn.com/partners

Garrett, R. (2016). The state of open universities in the commonwealth: A perspective on performance, competition, and innovation. Commonwealth of Learning. Retrieved from http:// oasis.col.org/ handle/ 11599/2048 
Guri-Rosenblit, S. (1999). Distance and campus universities: Tensions and interactions - a comparative study of five countries. Oxford: Pergamon Press \& International Association of Universities.

Guri-Rosenblit, S. (2010). Digital technologies in higher education: Sweeping expectations and actual effects. New York: Nova Science.

Guri-Rosenblit, S. (2014). Distance education systems and institutions in the online era: An identity crisis. In T. Anderson \&O. Zawacki-Richter, O. (Eds.). Online distance education: towards a research agenda (pp. 109-129). Edmonton, AB: Athabasca University Press.

Guri-Rosenblit, S. (2018). E-teaching in higher education: An essential prerequisite for e-learning, J ournal for New Approaches in Educational Research, 7 (2), 93-97.

Harasim, L. (2012). Learning theory and online technologies. NewYork, NY: Routledge.

Keegan, D., \& Rumble, G. (1982). Distance teaching universities at university level. In G. Rumble \& K. Harry (Eds.), The distance teaching universities (pp. 15-31). London, England: Croom Helm.

Lane, A. (2017). Business models for OER and MOOCs beyond monetary incentives. In G. Ubachs, L. Konings, \& M. Brown (Eds.), The envisioning report for empowering universities (pp. 13-15). Maastricht, NL: European Association of Distance Teaching Universities.

Li, Y. (2012). Developing trend of open and distance education in China. Educational Technology Debate: Exploring ICT and Learning in Developing Countries . Retrieved from http:// edutechdebate.org/ open-and-distance-learning/ devloping-trend-of-open-anddistance-education-in-china

Millot, B. (2014). Top universities or top higher education systems? International Higher Education, $75,7-8$. https:// doi.org/ 10.6017/ ihe.2014.75.5427

Open University of Israel. (2019). National student survey. Retrieved from https:// www.openu.ac.il/en/pages/ Student-Survey.aspx

Pappano, L. (2012, November 14). The year of the MOOC. The New York Times. Retrieved from http:// www.nytimes/2012/ 11/ 04/ education/ edlife/ massive-open-online-courses-aremultiplying-at-a-rapid-pca.html

Perry, W. (1977). The open university. San Francisco: J ossey Bass.

Peters, O. (1983). Distance teaching and industrial production. In D. Sewart, D. Keegan, \&B. Holmberg (Eds.), Distance education: International perspectives (pp. 95-113). London: Croom Helm.

Peters, O. (1994). Distance education and industrial production: A comparative interpretation in outline. In M. Keegan (Ed.), Otto Peters on distance education (pp. 107-127). London: Routledge. 
Reddy, G. R. (1988). Open universities: The ivory towers thrown open. New Delhi: Sterling Publishers.

Rothblatt, S. (1991). The American modular system. In R. O. Berdhal, G. C. Moddie, \& I. S. Spitzberg (Eds.), Quality and access in higher education (pp. 129-141). Buckingham: The Society of Research into Higher Education and The Open University Press.

Rumble, G. (2014). The costs and economics of online education. In T. Anderson \& O. ZawackiRichter (Eds.), Online distance education: Towards a research agenda (pp. 197-216). Edmonton, AB: Athabasca University Press.

Shanghai Ranking. (2018). World university rankings: The open university. Retrieved from http:// shanghairanking.com/World-University-Rankings/ The-OpenUniversity.html

Shaw, B., \& Taylor, J . C. (1984). Instructional design: Distance education and academic tradition. Distance Education, 5(2), 277-285.

Tait, A. (2018). Open universities: The next phase. Asian Association of Open Universities J ournal, 13(1), 13-23. https:// doi.org/ 10.1108/AAOUJ -12-2017-0040

The International Telematic University. (2018). The international telematic university. Retrieved from https:// www.uninettunouniversity.net/ en/ default.aspx

Ubachs, G., Konings, L., \& Brown, M. (2017). The envisioning report for empowering universities. Maastricht, NL: European Association of Distance Teaching Universities. 